\title{
Estimation of Above Ground Biomass in Forests Using Alos Palsar Data in Kericho and Aberdare Ranges
}

\author{
Eunice Wamuyu Maina1* ${ }^{*}$, Patroba Achola Odera ${ }^{2}$, Mwangi James Kinyanjui ${ }^{3}$ \\ ${ }^{1}$ Department of Geomatic Engineering and Geospatial Information Systems, Jomo Kenyatta University of Agriculture and \\ Technology, Nairobi, Kenya \\ ${ }^{2}$ Division of Geomatics, School of Architecture, Planning and Geomatics, University of Cape Town, Cape Town, South Africa \\ ${ }^{3}$ Department of Forestry, School of Natural Resources and Environmental Studies, Karatina University, Karatina, Kenya \\ Email: *eunicemna@gmail.com
}

How to cite this paper: Maina, E. W. Odera, P. A., \& Kinyanjui, M. J. (2017). Estimation of Above Ground Biomass in Forests Using Alos Palsar Data in Kericho and Aberdare Ranges. Open Journal of Forestry, 7, 79-96.

https://doi.org/10.4236/ojf.2017.72006

Received: January 23, 2017

Accepted: March 17, 2017

Published: March 20, 2017

Copyright (c) 2017 by authors and Scientific Research Publishing Inc. This work is licensed under the Creative Commons Attribution International License (CC BY 4.0).

http://creativecommons.org/licenses/by/4.0/

\begin{abstract}
Above Ground Biomass is one of the six pools identified in the inventory of forest resources and estimation of greenhouse gas emissions and sinks from the forestry sector. The pool varies by management practices in different agroecological or agro-climatic zones in forests. The quantification of above ground biomass (AGB) hence carbon sequestration in forests has been very difficult due to the immense costs required. This research was done to estimate AGB using ALOS PALSAR L band data (HH, HV polarisation) acquired in 2009 in relation with ground measurements data in Kericho and Aberdares ranges in Kenya. Tree data information was obtained from ground measurement of DBH and tree heights in 100 circular plots of $15 \mathrm{~m}$ radius, by use of random sampling technique. ALOS PALSAR image is advantageous for its active microwave sensor using L-band frequency to achieve cloud free imageries, and the ability of long wavelength cross-polarization to estimate AGB accurately for tropical forests. The variations result between Natural and plantation forest for measured and estimated biomass in Kericho HV band regression value was 0.880 and $\mathrm{HH}$ band was 0.520 . In Aberdare ranges $\mathrm{HV}$ regression value of 0.708 and $\mathrm{HH}$ band regression value of 0.511 for measured and estimated biomass respectively. The variations can be explained by the influence of different management regimes induced human disturbances, forest stand age, density, species composition, and trees diameter distribution. However, further research is required to investigate how strong these factors affect relationship between AGB and Alos Palsar backscatters.
\end{abstract}

\section{Keywords}

Above Ground Biomass Estimation, Green House Gas, Carbon Credits, Alos 
Palsar Backscatter, Cross-Polarization, Regression Analysis

\section{Introduction}

Biomass refers to the material content in a forest (FAO, 2004). Its assessment allows valuation of the forest for purposes of carbon and available resource for energy. Forest Biomass in general is inclusive of the Above Ground and Below Ground living mass ( $\mathrm{Lu}, 2006)$. These include standing trees, shrubs, roots, creepers/climbers, and the dead mass of fine and coarse litters associated with the soil. However, from most previous research (Steininger, 2000; Zheng et al., 2004; Lu et al., 2005), there is difficulty in collecting field data of Below Ground Biomass. Moreover, unlike above ground biomass, below ground biomass is not immediately affected by common deforestation and degradation processes. This therefore makes most of research to focus on biomass estimation on Above Ground Biomass (AGB).

Remote sensing approaches offer considerable potential in support of forest monitoring as it provides long-term and repetitive observations over large areas. Satellite imagery based techniques provide an alternative to traditional methods by providing spatially explicit information and enable repeated monitoring, even in remote locations, in a cost-effective way (Patenaude et al., 2005; Rosillo-Calle et al., 2006). With the advantage of providing spatial, temporal, and spectral information (Brown, 2002), remote sensing can be used as a tool to estimate carbon. Difficulties have been experienced to acquire cloud free images in tropical regions hence a key challenge in using the widely available optical remote sensing data.

Space-borne synthetic aperture radar (SAR) sensors such as the L-band ALOS PALSAR, is an active system, transmitting microwave energy at wavelengths from 3.0 (X-band) to $23.6 \mathrm{~cm}$ (L-band). The major advantage of SAR systems is their weather and daylight independence. In addition, the ability to penetrate into the volume of the object (canopies) which depend on the wavelength is another important character (Lu et al., 2005).

The degree of penetration depends on the wavelength so the sensor's ability to estimate biomass. The ability to measure biomass is additionally affected by the polarization and the incidence angle of the sensor, and land cover and terrain properties (Lu et al., 2005). ALOS PALSAR is one of the most promising remote sensors to map above-ground forest carbon stock. Many studies have shown that long-wavelength radar data are sensitive to above-ground biomass (AGB).

This work aimed at estimating AGB in plantation and Natural forest through application of remote sensing technique using ALOS PALSAR L-band backscatter and forest biomass for a large range of $\mathrm{AGB}$ values.

The selection of the study area was based on availability of various characteristics of a typical tropical forest in Kenya, data availability and accessibility. The chosen study area for this research was Kericho that lies within longitudes 
$35^{\circ} 02^{\prime} \mathrm{E}$ and $35^{\circ} 40^{\prime} \mathrm{E}$ and between the Equator and latitude $0^{\circ} 23^{\prime} \mathrm{S}$ in the highland west of the Great rift-valley in Kenya. The Forest Reserve occupies a total area of 32,700 ha. The area is traversed by three agro-climatic zones-humid, Semi humid and sub humid. The soils are imperfectly drained, very deep, dark grey to black vertisols (Bationo et al., 2006).

The Aberdare forest is within longitudes $36^{\circ} 30^{\prime} \mathrm{E}$ and $36^{\circ} 55^{\prime} \mathrm{E}$ and latitudes $0^{\circ} 45^{\prime} \mathrm{S}$ and $0^{\circ} 05^{\prime} \mathrm{S}$ the area is traversed by four counties-Kiambu, Murang'a, Nyeri and Nyandarua with four agroclimatic zones-humid, Semi humid, sub humid and semi humid to arid. Aberdare Ranges have inherent high fertility, being of basaltic origin. They are well drained, normally very deep, dark reddish brown, clays with a humid top-soil layer. Figure 1 shows the location of sampling plots of the study area in Kericho and Aberdare Ranges.

\section{Methods}

ALOS-PALSAR images with $\mathrm{HH}$ polarization and $\mathrm{HV}$ polarization were used to calculate the backscattering coefficient. The DN (Digital Number) of the $\mathrm{HH}$ and $\mathrm{HV}$ polarized images were converted into backscattering coefficient values using Equation (1) (Shimada et al., 2009). There are two major steps involved in this study, namely, ground measurements sampling and preprocessing of satel-

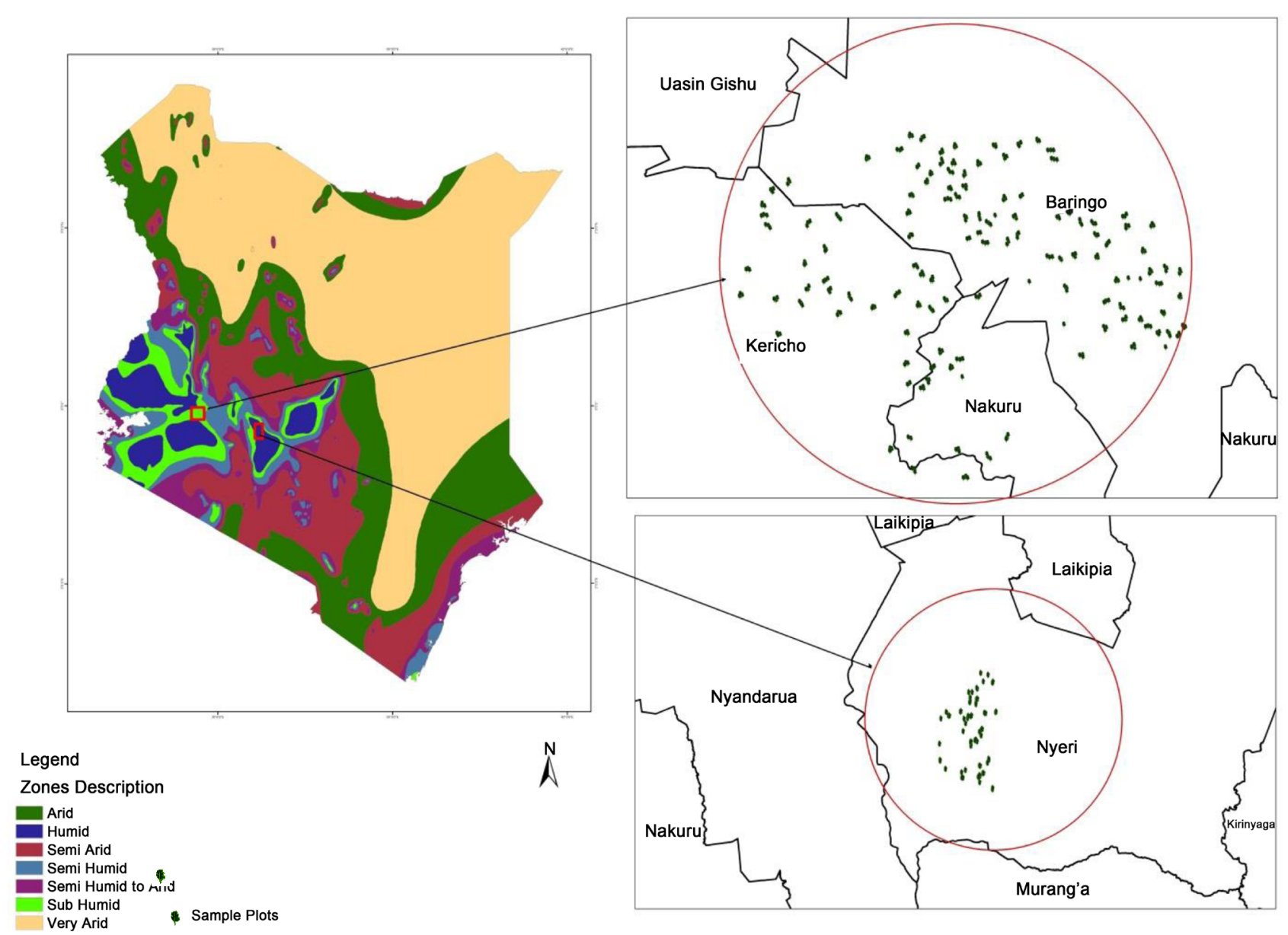

Figure 1. Study area-Kericho (top red circle) and Aberdare Ranges (bottom red circle). 
lite imageries. A total number of 100 circular plots of radius $15 \mathrm{~m}$ were established.

$$
\sigma^{\circ}=10 * \log 10(D N 2)+C F \text {, }
$$

where $\sigma^{\circ}$ is back-scatter coefficient, $D N$ is Digital number value and $C F$ is Calibration Factor (taken as -83 in this study).

The Diameter measurement was done at Breast Height (DBH) for all trees stand inside the plots and also the height. The allometric Equation (2) was used for ground measured biomass estimation for the trees. The AGB was calculated based on mass per hectare, which gives the units of $\mathrm{Mg} / \mathrm{ha}$. Several variables were derived from ALOS PALSAR images that were correlated with the measured AGB on the ground.

$$
\begin{aligned}
B= & -0.01213-0.000003968 \times\left(D_{1.3}\right)^{2}+0.0002551 \times D_{1.3} \times h \\
& +0.000026 \times\left(D_{1.3}\right)^{2} \times h
\end{aligned}
$$

where $B$ is the Biomass, $D_{1.3}$ is the Diameter at Breast height (Diameter is measured at the height of 1.3 metres from the ground level) and $h$ is the Height.

The microwave energy transmitted that penetrates the forest canopies is largely dependent on the size and orientation of canopy structural elements, such as leaves, branches and stems. ALOS PALSAR has two polarizations, horizontal $(\mathrm{HH})$ and vertical $(\mathrm{HV})$ polarimetry. In this study HV responded strongly than $\mathrm{HH}$ in estimating AGB. However both polarizations were used in this study to investigate their correlations. By use of the strongest HV correlations coefficient factor, the empirical prediction model to estimate AGB for the study area was established.

\subsection{Field Work}

The purpose of the fieldwork phase was to measure the biophysical parameters such as $\mathrm{DBH}(\mathrm{cm})$, tree height $(\mathrm{m})$ from the study area. To execute a forest inventory, we need to establish a relationship between directly measurable tree or stand characteristics (e.g. DBH, height) and other forest stand parameters such as volume or biomass which is impossible to be measured directly (Husch et al., 2003). Therefore, the stand parameters of tropical forest was actually measured from the field and then used for biomass calculation by use of allometric equations.

\subsubsection{Sampling Design}

Sampling was done on two unique forest management systems. The forests lie in different agro-ecological/agro-climatic zones. Kenya is divided into 7 agro-climatic zones using a moisture index (Sombroek et al., 1982) based on annual rainfall expressed as a percentage of potential evaporation. Areas with an index greater than $50 \%$ have high potential for cropping, and are designated zones I, II, and III. These zones account for $12 \%$ of Kenya's land area. The semi-humid to arid regions (zones IV, V, VI, and VII) have indexes of less than $50 \%$ and a mean annual rainfall of less than $1100 \mathrm{~mm}$.

The study areas sample plots in Kericho and Aberdares should be lie in agro- 
climatic zone II and III respectively. The sampling targeted all the tree species within the sampling units. The data collection was done for all the tree species for the two study areas. The sampling units were for plantation and Natural forest where an average total number of 30 species was for Natural forest and 20 tree species for plantation forest.

\subsubsection{Sample Units}

The established sampling unit was circular plot with a radius of 15 meters. A total number of fifty plots were measured in Kericho and Aberdare respectively in areas of plantation and natural forests. There were 80 plots in natural forests and 20 plots in plantation forests. The aim of the field measurements was to capture the total amount of biomass on the sample plots. All trees within $15 \mathrm{~m}$ radius with diameter at breast height $(\mathrm{DBH})$ of at least $5 \mathrm{~cm}$ were measured and also the standing height as shown in Figure 2.

\subsubsection{Sample Plots Establishment}

All the plots were generated with a cell size of $25 \times 25 \mathrm{~m}$. The cell size corresponds to the area of a reference sample plot and the radius was chosen to be 15 $\mathrm{m}$. The random forest sampling method was applied for location of the study plot in both areas.

Sample plot information for every tree species was collected. A separate copy of Sample Plot Form was filled for each sample plot. The form contained general data describing the sample plot, including the information on its identification code and whether the plot can be accessed or not.

\subsection{Field Data Analysis}

There have been many previous studies on the tree and stand level modelling in

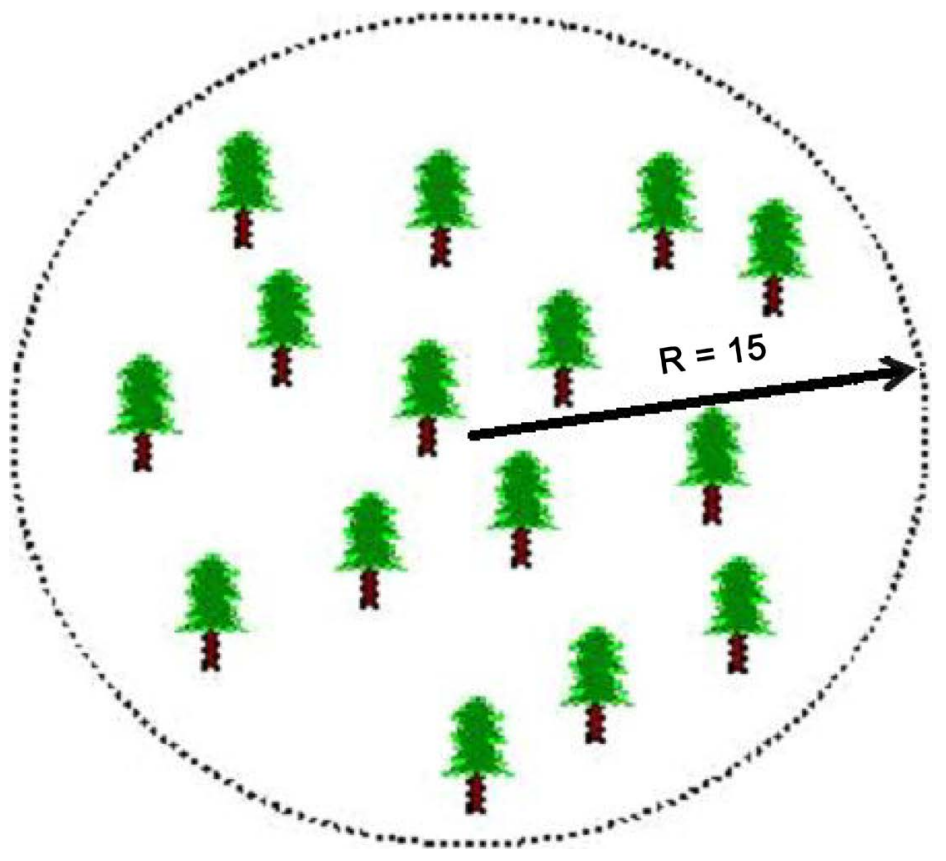

Figure 2. A circular sample plot with a radius (R) of 15 meters. 
Kenya and other Eastern African countries. However, the focus has mainly been on plantation tree species such as Pinus patula, P. radiata, Cupressus lusitanica and Eucalyptus sp. and the main focus has been on stand growth and yield rather than individual trees. Furthermore, the models are often based on data from restricted areas and may not be relevant at the national scale. Equations to predict tree biomass has been considered only recently because of the increasing importance to estimate the forest carbon stocks.

Allometric equations were used to calculate the ABG biomass from volumetric or structural dimensions and most of them are based on tree diameter at breast height and tree height. Various allometric equations have been developed for tropical rain forest (Brown, 1997; Araújo et al., 1999; Chambers et al., 2001; Chave et al., 2005; Basuki et al., 2009). However, according to literature review, only one allometric equation to estimate AGB biomass from bio physical parameters Heights and DBH was available locally for the study area. Kinyanjui et al. (2014) used Equation (2) for montane forests of Kenya. The AGB per tree was then summed over all the trees in the plot and expansion factor used to obtain a stand-level AGB estimate per plot for the two sites.

\subsection{ALOS PALSAR Data}

ALOS (Advanced Land Observing Satellite) is designed as a follow-on to the JERS-1 and ADEOS (Midori). Besides PRISM (for stereoscopic mapping) and an AVINIR, ALOS carries a phased array L band SAR, known as PALSAR. The SAR has a swath width of $70 \mathrm{~km}$ and a 2 look spatial resolution of $10 \mathrm{~m}$ in its observation mode, and a swath width of $250-360 \mathrm{~km}$ with a spatial resolution of $100 \mathrm{~m}$ in a Scan SAR (wide swath width) mode (Shimada et al., 2009).

The ALOS PALSAR data used for this research was acquired in January 2009 with 2 polarisation $\mathrm{HH}$ and $\mathrm{HV}$. It was a fine mode product with level 1.5. The preprocessing parameters used are as shown in Table 1.

The Alos Palsar image contains pixels values of original backscatter $(\sigma, \mathrm{dB})$ from $\mathrm{HH} \& \mathrm{HV}$ polarizations $\mathrm{HV} / \mathrm{HH}$ a simple ratio generation was done by dividing $\mathrm{HH}$ by $\mathrm{HV}$ polarizations. The RGB bands composite was generated from $\mathrm{HH}, \mathrm{HV}$ and $\mathrm{HH} / \mathrm{HV}$ L-band respectively as represented in Figure 3.

Table 1. Processing parameters of level 1.5 fine mode

\begin{tabular}{cc}
\hline Processing Mode & Parameters \\
\hline $\begin{array}{c}\text { Map projection } \\
\text { Framing } \\
\text { Image direction }\end{array}$ & UTM \\
Resampling & Map \\
Geodetic coordinate (Earth mode) & Nearest Neighbour, Bi-linear, Cubic Convolution \\
Scene Shift & GRS80 \\
Window function & -5 to 4 \\
Multi -look number & Rectangle \\
Pixel spacing & 4 looks \\
& $12.5 \mathrm{~m}$
\end{tabular}



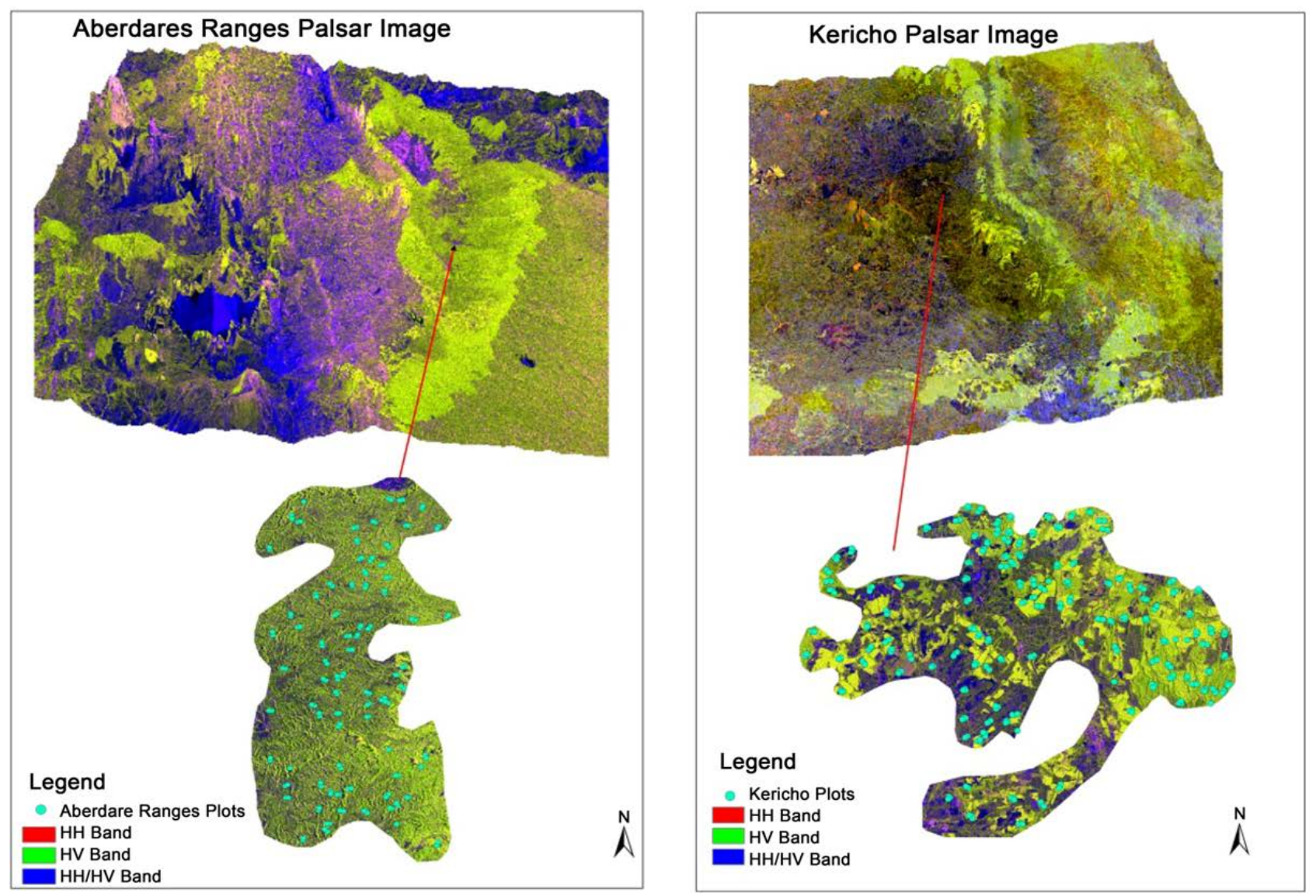

Figure 3. Aberdares Ranges and Kericho Alos palsar RGB.

The images used for this study were already processed. The images acquisition and corrections was done using the SRTM $30 \mathrm{~m}$ resolution and then DN values were converted to Palsar backscatter using Equation (1).

The back-scatter values were converted to Above Ground Biomass (AGB) for both $\mathrm{HH}$ and $\mathrm{HV}$ bands, using Equation (3).

$$
\text { Forest } A G B=\exp \left[\left(\sigma^{\circ}{ }_{H V}+23.44\right) / 2.077\right] \text { (Avtar et al., 2012) }
$$

\subsection{Estimation of Above Ground Biomass}

In this study, correlation analysis was used to assess the degree of association of biophysical parameters, AGB with radar backscatter and DN value from fusion data. Regression analysis is a common way to develop AGB estimation models (Lu, 2006). Long wavelength in SAR L-band is more reliable for AGB estimation.

Correlation analysis measures the degree of association between two or more variables. Correlation expresses the joint property or relationship between two or more variables to see how closely they are associated. When correlation exists, the size of the measurements of one variable is related to the sizes of the measurements of another variable (Husch et al., 2003).

The measure of the degree of association between two variables is called the correlation coefficient. It takes value between -1 and 1 , where -1 indicate a perfect negative relation, +1 a perfect positive relation and the value of 0 indicates 
absence of relation (Stein et al., 1999).

The objective of regression analysis is to quantify the relationship between dependent variable and one or more independent variables. Regression implies a cause and effect relationship in which a change in the value of an independent variable will result in an expected average change in the dependent variable. The quantitative relationship is expressed by an equation and its graphic representation (Husch et al., 2003). The square value of the correlation coefficient $\left(R^{2}\right)$ is called the coefficient of determination. It can be interpreted as indicating the percentage of variation in one variable that is associated with other variable (Husch et al., 2003).

\section{Results and Discussion}

\subsection{Results}

The total biomass estimation from ground data was presented by use of boxplots shown in Figure 4 for Natural and plantation forest of the two study areas respectively. The plots analysed for each study area was 40 plots for natural forest and 10 plots for plantation forest.

The estimated ground measurement biomass for Aberdare ranges forest was slightly higher than the Kericho area as represented in Figure 4. The plantation forest in Aberdare has less biomass than the Kericho study area. The highest plot in Aberdare ranges recorded 8844 kilograms per plot. The plantation forest in Kericho recorded more biomass in all the plots than the Natural forest. The highest in plantation forests was 2037 kilograms per plot.

In Figure 5 the biomass estimate and biomass measured in both L-Band $\mathrm{HH}$ and HV are correlated where the results in box graph indicates high biomass value in $\mathrm{HV}$ band in natural forest while the $\mathrm{HH}$ band for the area has low biomass value. This indicates that the HV band has strong correlation in Natural forest than $\mathrm{HH}$ band for the two study areas.

Plantation forest in Kericho plantation is presented in Figure 6. The Forest plantation had a strong regression value of 0.705 . The $H V R^{2}$ was weak in the natural forests with a value of 0.421 .

The HV correlation in natural forest was stronger with a regression coefficient of 0.647 . The $\mathrm{HH}$ was weak with a correlation coefficient of 0.487 as shown in Figure 7.

Biomass in Aberdare Forest

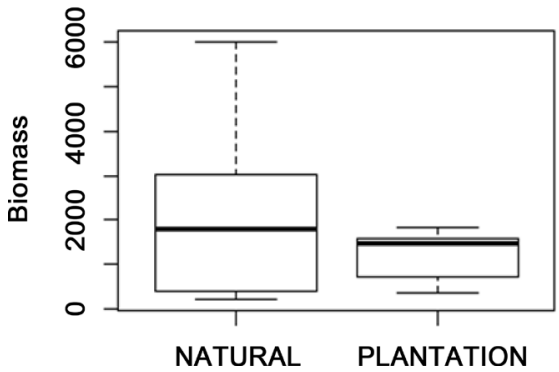

Biomass in Kericho

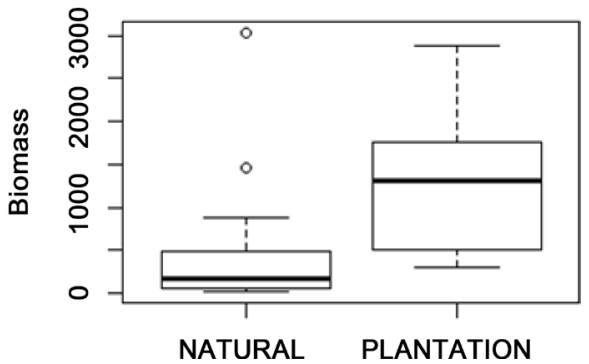

Figure 4. Kericho and Aberdares Ranges Biomass. 


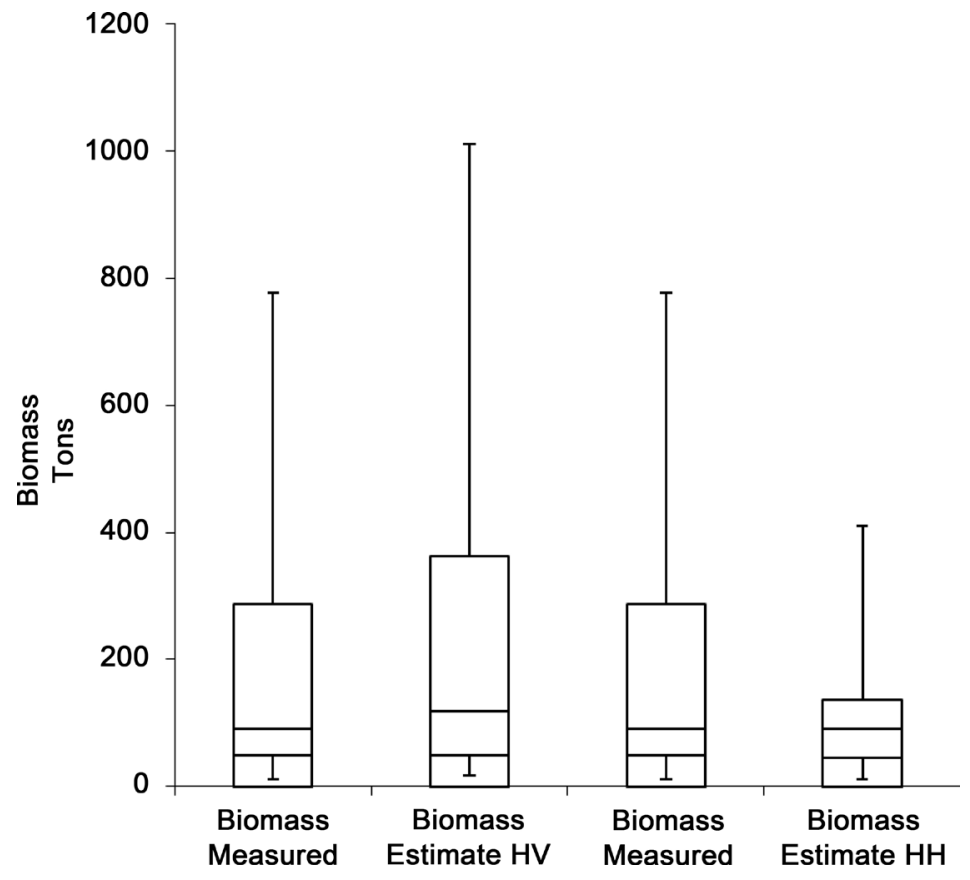

Figure 5. Biomass estimate and biomass measured in both L-Band $\mathrm{HH}$ and $\mathrm{HV}$.

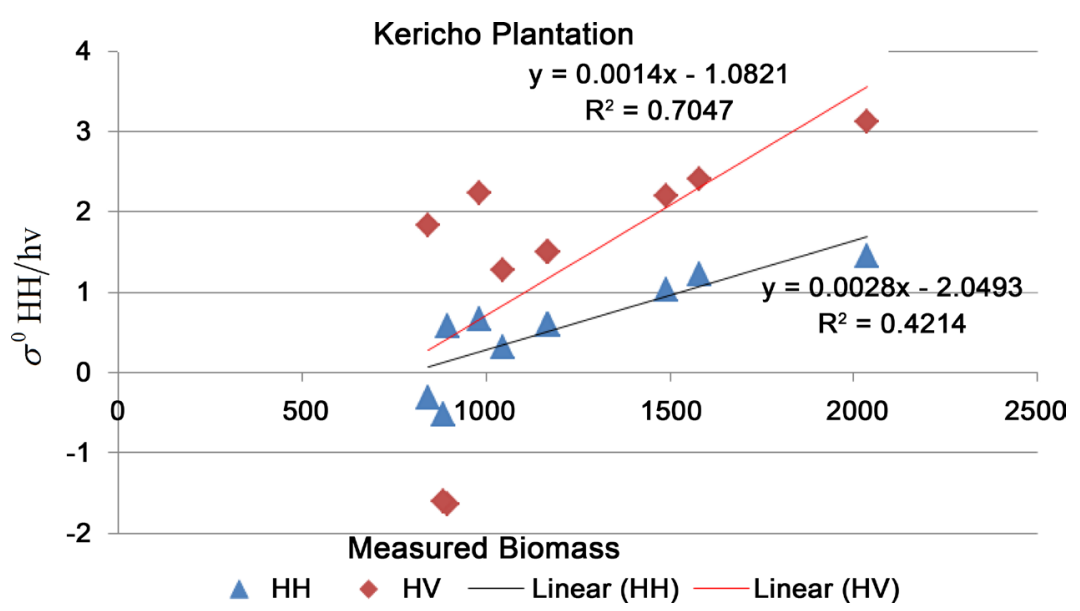

Figure 6. Kericho Forest plantation $\mathrm{HH}$ and HV backscattering $\left(\mathrm{R}^{2}\right)$.

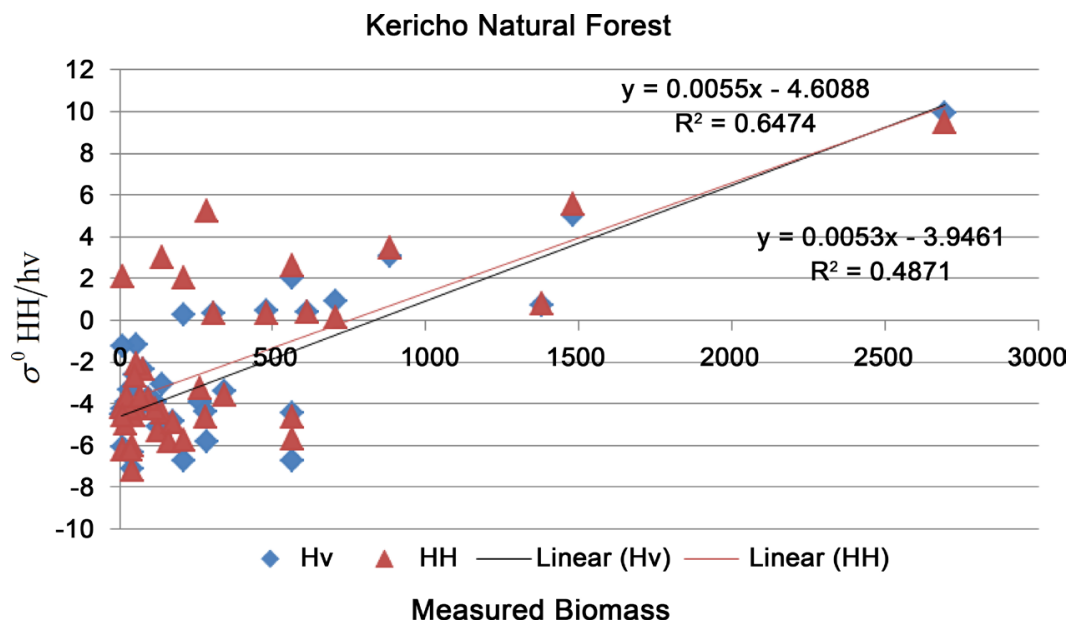

Figure 7. Kericho Natural Forest $\mathrm{HH}$ and $\mathrm{HV}$ backscattering regression $\left(\mathrm{R}^{2}\right)$. 
In Figure 8 the results represented HV estimated biomass in Kericho, very strong with a regression of 0.880 against the $\mathrm{HH}$ backscattering which had a weak regression value of 0.520 .

In Figure 9 the Aberdare ranges Natural forest shows a better correlation of $\mathrm{HV}$ in Natural forest of 0.753 while the $\mathrm{HH}$ backscattering coefficient was weak with a value of 0.514 .

Figure 10 shows Aberdare Forest, the HV backscattering coefficient value as relatively strong with a regression value of 0.613 against the $\mathrm{HH}$ band with a value of 0.450 .

As shown in Figure 11 the total biomass estimated correlation with the biomass measured in Aberdare was strong in $\mathrm{HV}$ band 0.708 unlike in the $\mathrm{HH}$ band which recorded a regression value of 0.511 .

As represented in the box graph below in Figure 12, the above ground measured biomass in correlation with biomass estimation from L band HV backscatter is high in comparison with biomass estimation from $\mathrm{L}$ band $\mathrm{HH}$.

The correlation analysis was employed again using Pearson correlation coeffi-

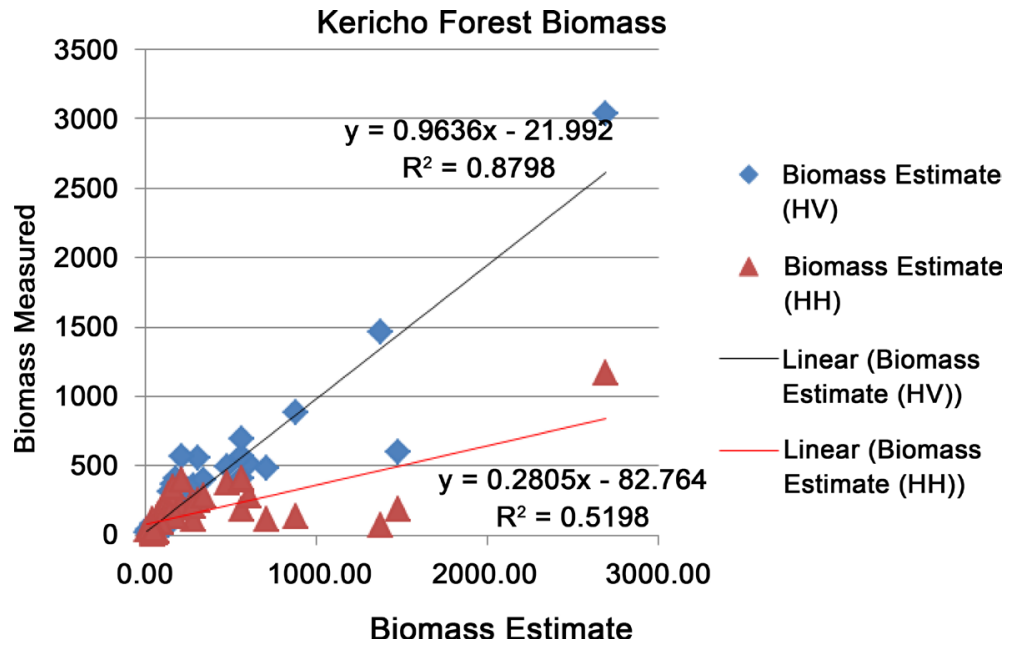

Figure 8. Kericho Forest Biomass correlation against the Measured and Estimated.

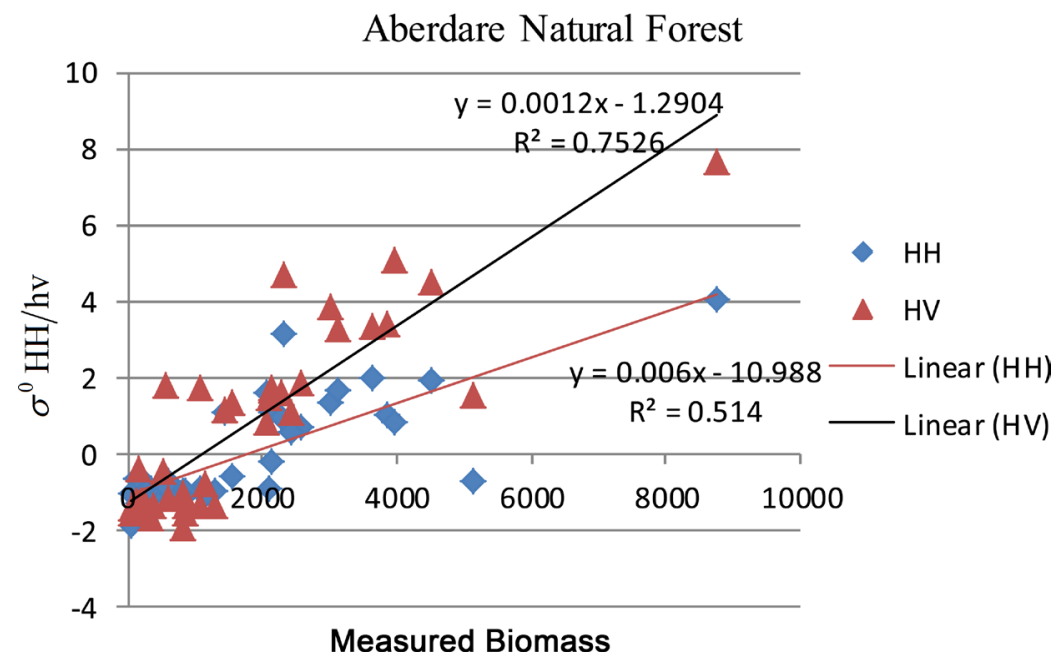

Figure 9. Aberdare Natural Forest $\mathrm{HH}$ and $\mathrm{HV}$ backscattering regression $\left(\mathrm{R}^{2}\right)$ value. 


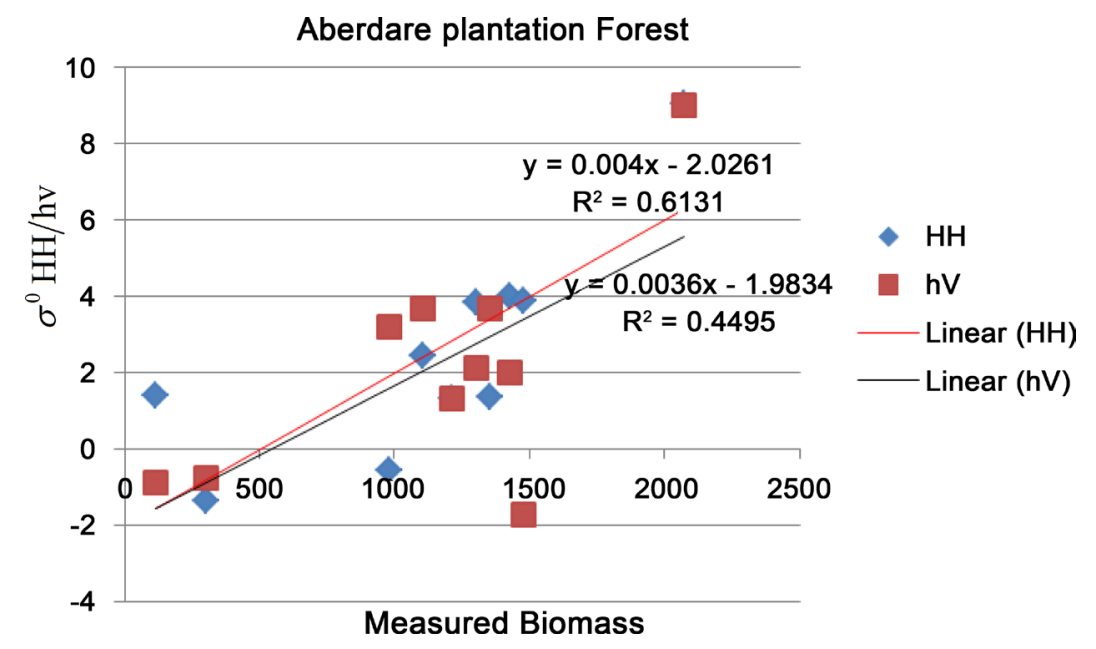

Figure 10. Aberdare Plantation Forest $\mathrm{HH}$ and HV backscattering regression $\left(\mathrm{R}^{2}\right)$ value.

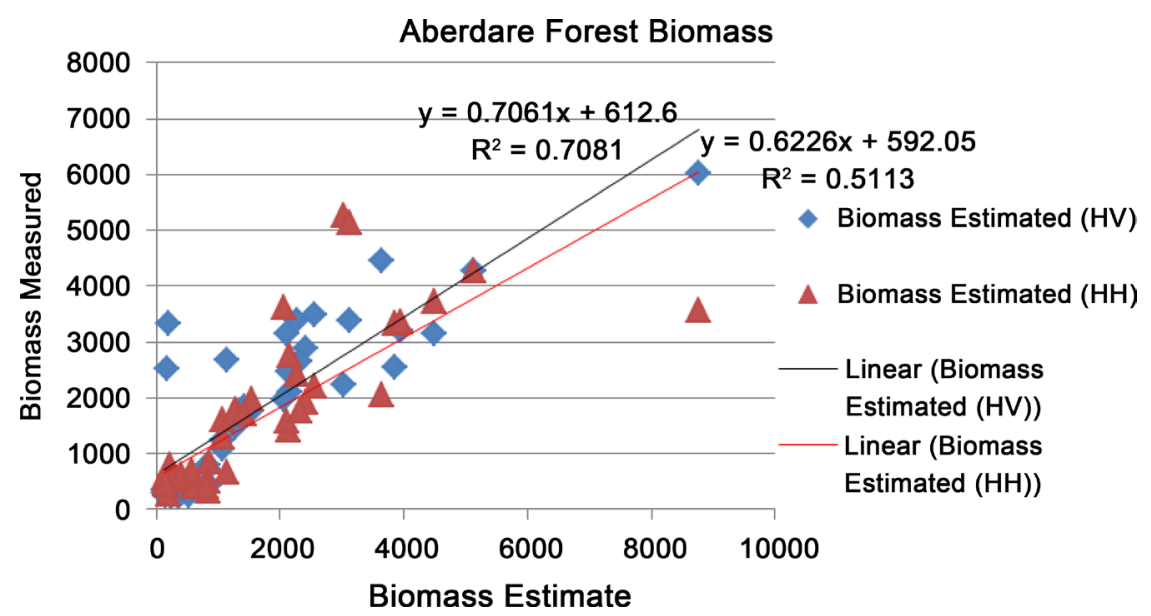

Figure 11. Aberdare Ranges Forest Biomass correlation against the Measured and Estimated.

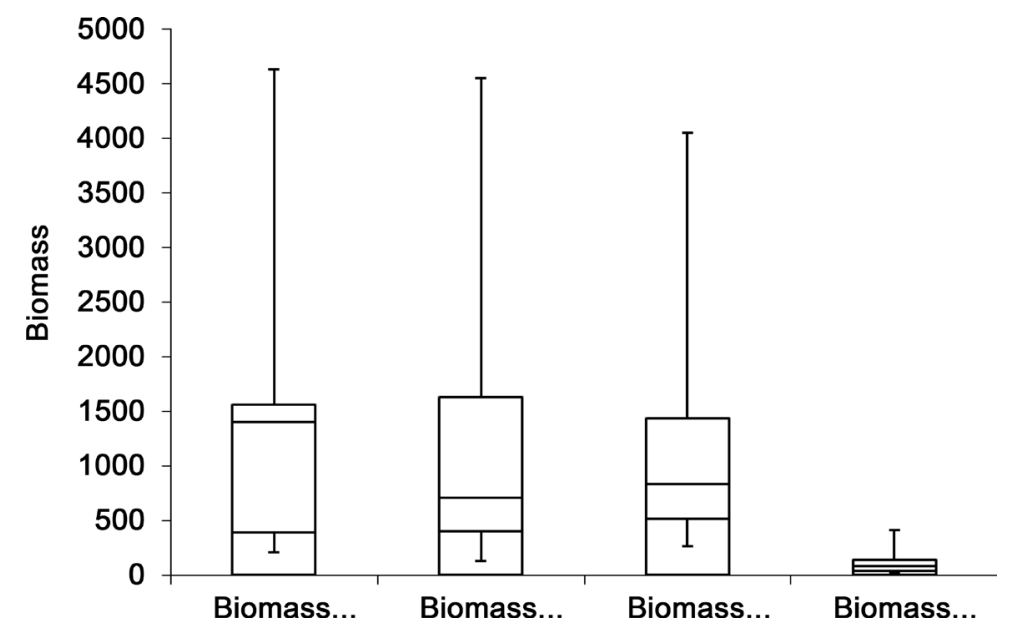

Figure 12. Aberdare Ranges Forest Biomass correlation against the Measured and Estimated $\mathrm{HH}$ and $\mathrm{HV}$ L-band.

cient to see the effect of this variation in HH and HV L-band in AGB estimation. Table 2 shows confidence level of $95 \%$ the HV band in Plantation and Natural 
forest that was very strong with a coefficient value of 0.880 and 0.708 respectively.

The $\mathrm{HH}$ band was relatively weak in both scenarios at the same confidence level with a value of 0.511 in natural forest and 0.520 in plantation. Therefore these results affirm the strength of HV L-band in estimating AGB.

The land cover classification result of the total study area of Kericho site was calculated and presented in Table 3. The highest land cover class was Forestland with an area of 17,487.3 hectares. The settlements had the lowest coverage of 9.8 hectares. The classification is as shown in Figure 13. The correlation between the land cover and the biomass map indicates that the area under forestland has the highest biomass value. These areas have the biomass values ranging between 2100 to $3500 \mathrm{Mg} / \mathrm{ha}$ while the areas under cropland and grassland recorded lowest value below 700 and $1400 \mathrm{Mg} / \mathrm{ha}$.

The spatial representation of biomass in the Kericho study area is as shown in Figure 14 which represents the above ground biomass distribution in the area from the highest to the lowest figure in $\mathrm{Mg} / \mathrm{ha}$. The lowest biomass was below $700 \mathrm{Mg} / \mathrm{ha}$ while the highest was $3500 \mathrm{Mg} / \mathrm{ha}$.

Aberdare ranges land cover area had 3 classes as shown in Figure 15. The highest land cover area was forestland with an area of 14,513.8 hectare and lowest was cropland. Table 4 shows the total coverage of the land cover area of the classification.

Figure 15 shows spatial representation of the above ground biomass in the Aberdare Ranges. The biomass spatial distribution (the highest to the lowest biomass value) in the Aberdares Ranges is shown in Figure 16.

Table 2. Pearson product correlation.

\begin{tabular}{ccccc}
\hline & \multicolumn{4}{c}{ Pearson Product Correlation } \\
\hline & \multicolumn{2}{c}{ Natural Forest } & \multicolumn{2}{c}{ Plantation Forest } \\
\hline $\mathrm{HH}$ & $\mathrm{HV}$ & $\mathrm{HH}$ & $\mathrm{HV}$ \\
\hline $\mathrm{t}$ & -0.329 & -0.448 & -0.911 & -0.602 \\
$\mathrm{df}$ & 39 & 39 & 9 & 9 \\
P-Value & 0.004 & 0.007 & 0.001 & 0.002 \\
$95 \%$ confidence & 0.246 & 0.277 & 0.255 & 0.248 \\
interval & 0.707 & 0.886 & 0.884 & 0.882 \\
Correlation Coefficient & 0.511 & 0.709 & 0.520 & 0.880
\end{tabular}

Table 3. Kericho land cover classification.

\begin{tabular}{cc}
\hline Classification & Area (Ha) \\
Settlements & 9.8 \\
Grassland & 5251.7 \\
Forestland & $17,487.3$ \\
Cropland & 2609.6 \\
Total & $\mathbf{2 5 , 3 5 8 . 4}$ \\
\hline
\end{tabular}




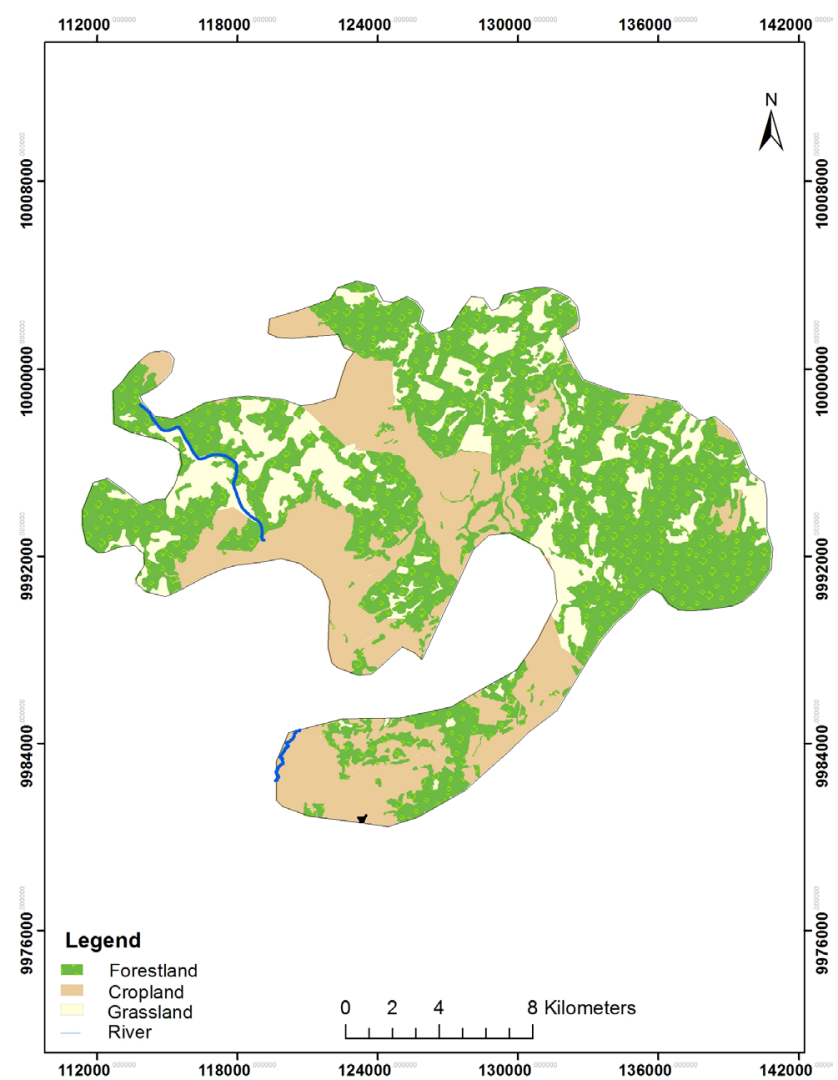

Figure 13. Kericho land cover map.

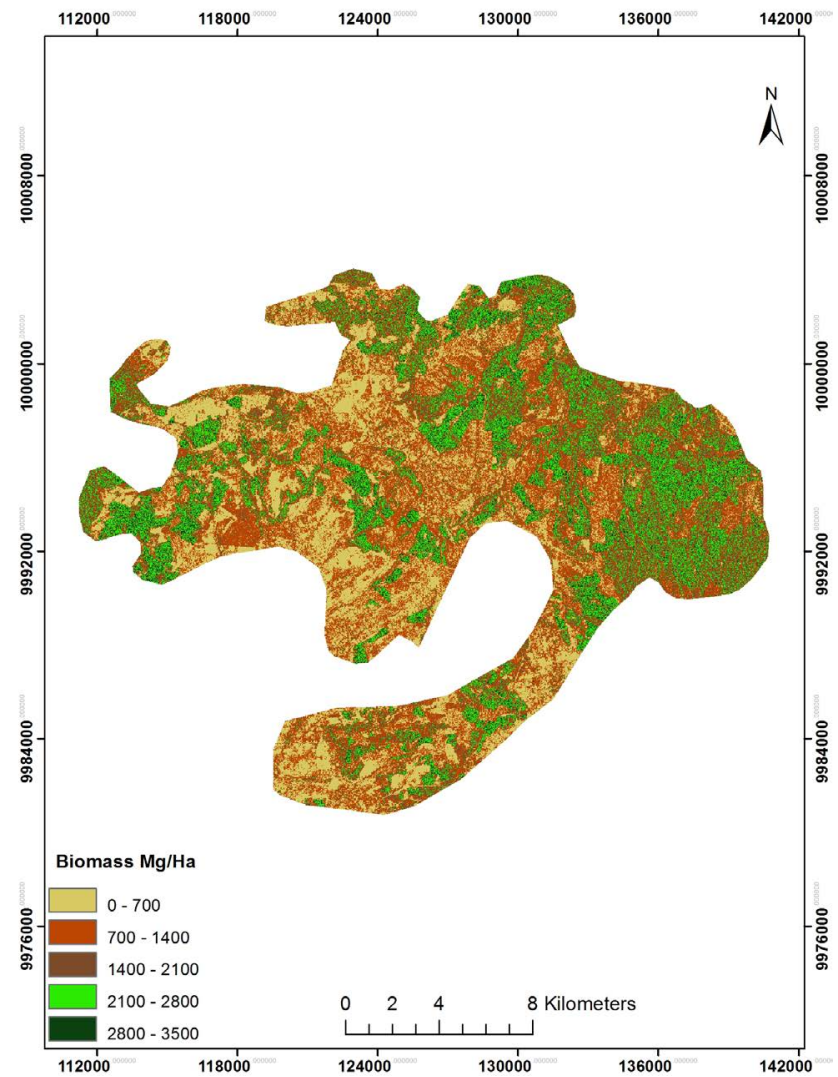

Figure 14. Kericho biomass map. 


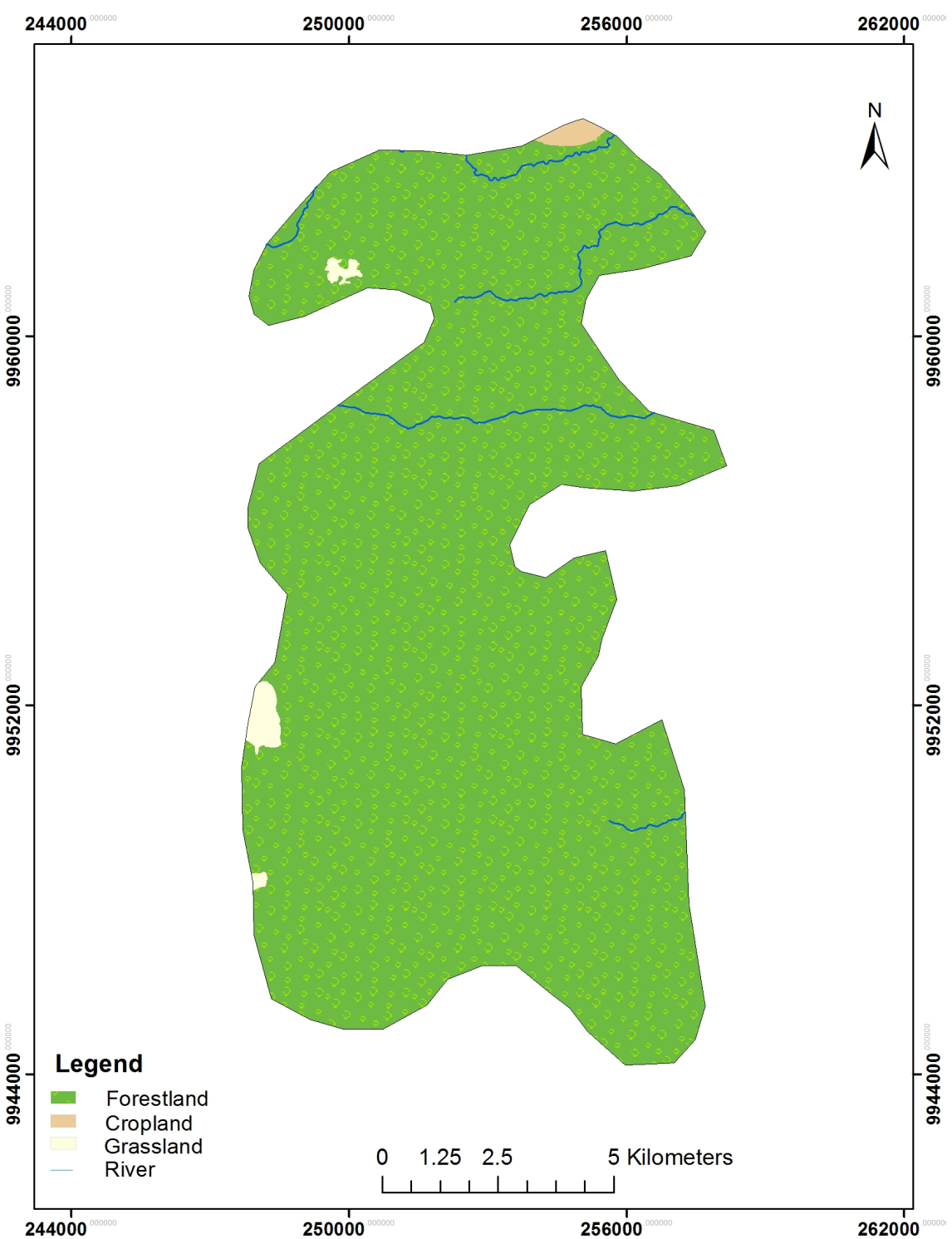

Figure 15. Aberdares Ranges Land Cover.

Table 4. Aberdare ranges land cover classification.

\begin{tabular}{cc}
\hline Classification & Area (Ha) \\
Grassland & 121.5 \\
Forestland & $14,513.8$ \\
Cropland & 54.1 \\
Total & $\mathbf{1 4 , 6 8 9 . 4}$ \\
\hline
\end{tabular}

\subsection{Discussion}

Standing biomass of a given tree species is mainly a function of $\mathrm{DBH}$, tree height and density which depends on tree age, forestry practices and also environmental and genetic factors (Kasischke and Christensen, 1990). Therefore, there must be a good relationship between radar backscatter and biophysical parameters to exploit the use of SAR backscatter to determine AGB since radar energy respond 


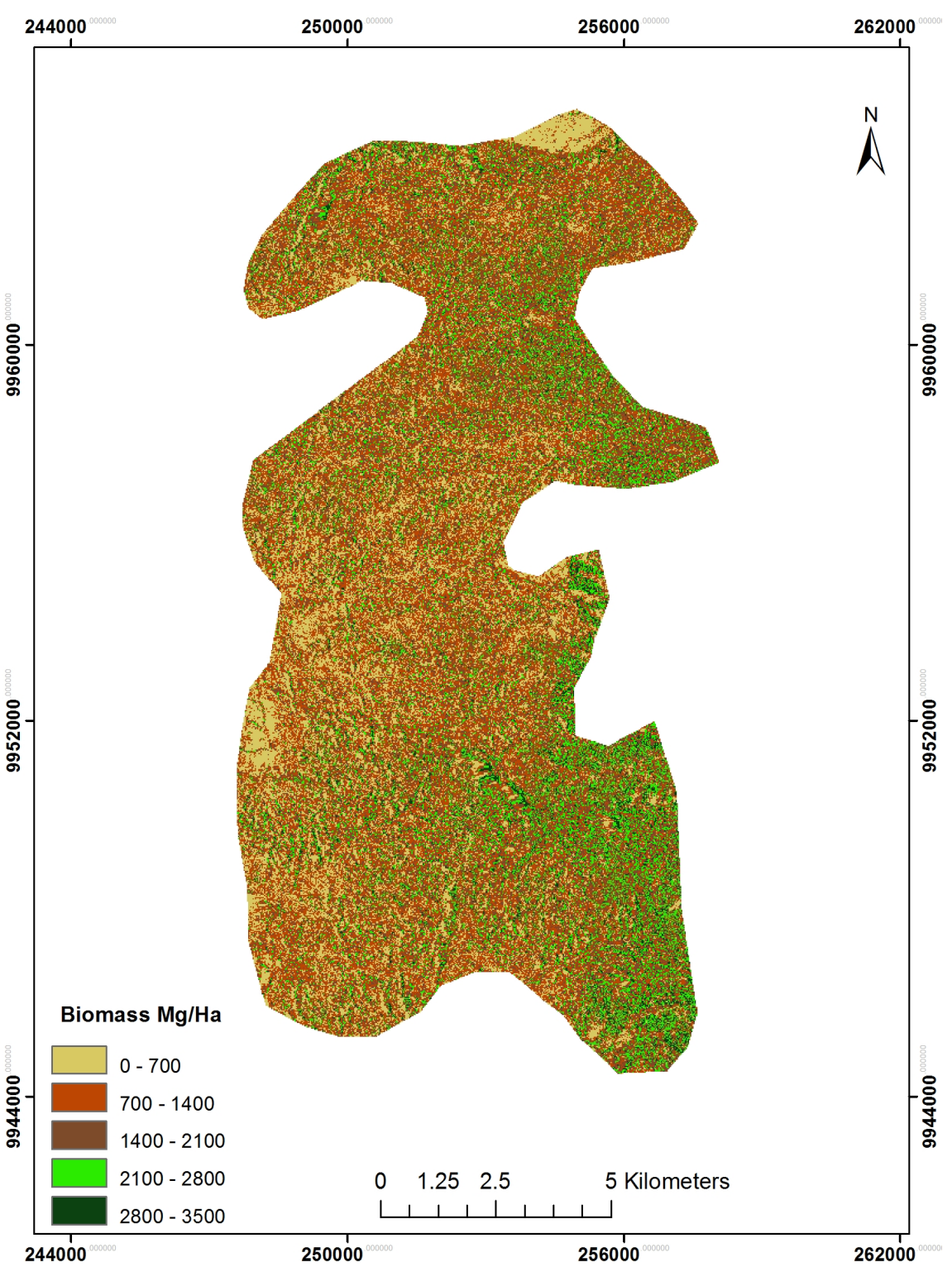

Figure 16. Aberdares ranges biomass map.

to biophysical characteristics of forest. Correlation of two Palsar backscatter types (L-band HH, L-band HV) and forest stand parameter measured from the field was analysed and the results are shown in section 3.1.

Strongest correlation was found with HV polarised L-band backscatter in Natural forest in Kericho and Aberdares ranges. The other correlations of $\mathrm{HH}$ polarised L-band was not strong in Natural forest neither in plantation. These results compared the ground measured biomass and estimated biomass from the Alos Palsar Images. The total biomass from ground measurement in Aberdare ranges was 69,159 tons while the estimated biomass was 66,741 tons in forest plantation. The regression value was 0.880 for HV L-band and 0.520 for $\mathrm{HH}$ L-band. In Natural and plantation forest the measured and estimated biomass for Kericho sites, HV L-Band regression value was 0.708 and HH L-Band value was 0.511 . The total measured biomass for plantation was $12,098.39$ and esti- 
mated biomass values was 12,263.41 for Natural forest the measured was 13,500.99 and estimated biomass was $13,889.11$.

The variations of the biomass can be explained by the different agro climatic conditions and also management practices. Other factors are due to Microwave interaction that depends on the angle of incidence and wavelength of the ALOS Palsar. $\mathrm{X}$ and $\mathrm{C}$ bands interact with the top part of the canopy layers. In L-band, the Palsar waves penetrate through the primary, secondary branches, trunks and ground. It is illustrated that there exists the relationship between the $\mathrm{X}, \mathrm{C}$, L-band Palsar backscatter and forest biomass and growing stock volume (Tansey et al., 2004).

According to the results from the two study areas the HV L-band had strong correlations in all the forest and hence adopted in this research to compute biomass estimation value for the forest. More strength is alluded by the Pearson product correlation where at confidence level of 95\% the $\mathrm{HV}$ band in Plantation and Natural forest was very strong with a coefficient value of 0.880 and 0.709 respectively as shown in Table 2 .

In plantation forest, the correlation variations were due to possibly the gap in management status of sampling plots obtained from the field. This could be improved if the sampling plots could be stratified base on the different managements. However, this could not be done due to the limitation of number of plots obtained from plantation.

In another research, (Beaudoin et al., 1994) concluded that linear regression analysis between backscatter coefficients of forest stands and each forest parameter resulted in a higher correlation at $\mathrm{HV}$, followed by $\mathrm{HH}$ with general forest parameter such as stand height, $\mathrm{DBH}$, tree and stand basal area.

\section{Conclusion}

The objective of this research was to estimate and map Above Ground Biomass (AGB) in plantation and Natural forest using Alos Palsar data. To achieve this, correlation analysis was used to assess the relation of AGB and other stand parameter measured from the field with Palsar backscatter extracted from L-band $\mathrm{HH}$ and $\mathrm{HV}$ polarization. After that, a linear regression model was established with the chosen inputs from previous correlation analysis to estimate AGB. The AGB in the natural forest could be estimated and mapped accurately using the linear regression of L-band $\mathrm{HH}$ and $\mathrm{HV}$. The plantation forest had a weaker correlation in $\mathrm{HV}$ but strong in $\mathrm{HH}$ backscatter. The strong correlation of $\mathrm{HV}$ of 0.753 developed the biomass estimation equation $y=0.0116 x-12.904$. $y$ denotes the biomass value while $\mathrm{x}$ is the HV value. The equation was used for biomass maps generation for the Kericho and Aberdares study areas.

ALOS PALSAR images are advantageous for its active microwave sensor using L-band frequency to achieve cloud free imageries. The data has never been used in Kenya for biomass estimation. Owing to the challenges that are faced on the estimation of biomass in tropical rain forest in Kenya, the images offer a solution. 


\section{References}

Araújo, T. M., Higuchi, N., \& de Carvalho, J. A. (1999). Comparison of Formulae for Biomass Determination in a Tropical Rain Forest Site the State of Pará, Brazil. Forest Ecology and Management, 177, 43-52. https://doi.org/10.1016/S0378-1127(98)00470-8

Avtar, R., Takeuchi, W., \& Sawada, H. (2012). Full Polarimetric PALSAR Based Land Cover Monitoring in Cambodia for Implementation of REDD Policies. International Journal of Digital Earth, 6, 255-275. https://doi.org/10.1080/17538947.2011.620639

Basuki, T. M., van Laake, P. E., Skidmore, A. K., \& Hussin, Y. A. (2009). Allometric Equations for Estimating the Above-Ground Biomass in Tropical Lowland Dipterocarp Forests. Forest Ecology and Management, 257, 1684-1694.

https://doi.org/10.1016/j.foreco.2009.01.027

Bationo, A., Hartemink, A., Lungu, O., Naimi, M., Okoth, P., Smaling, E., \& Thiombiano, L. (2006). African Soils: Their Productivity and Profitability of Fertilizer Use. Abuja: Background Paper Prepared for the African Fertilizer Summit June 2006.

Beaudoin, A., Le Toan, T., Goze, S., Nezry, E., Lopes, A., Mougin, E., Hsu, C. C., Han, H. C., Kong, J. A., \& Shin, R. T. (1994). Retrieval of Forest Biomass from SAR Data. International Journal of Remote Sensing, 15, 2777-2796. https://doi.org/10.1080/01431169408954284

Brown, S. (1997). Estimating Biomass and Biomass Change of Tropical Forests: A Primer. FAO Forestry Paper 134, Rome: For the Food and Agriculture Organization of the United Nations.

Brown, S. (2002). Measuring Carbon in Forests: Current Status and Future Challenges. Environmental Pollution, 116, 363-372. https://doi.org/10.1016/S0269-7491(01)00212-3

Chambers, J. Q., Santos, J. D., Ribeiro, R. J., \& Higuchi, N. (2001). Tree Damage, Allometric Characteristics Using Large-Footprint Lidar. Remote Sensing of Environment, 79, 305-319.

Chave, J., Andalo, A., Brown, S., Cairns, M. A., Chambers, J. Q., Eamus, D., Fölster, H., Fromard, F., Higuchi, N., Kira, T., Lescure, J.-P., Nelson, B. W., Puig, H., Riéra, B., \& Yamakura, T. (2005). Tree Allometry and Improved Estimation of Carbon Stocks and Balance in Tropical Forests. Oceologia, 145, 87-99.

https://doi.org/10.1007/s00442-005-0100-x

FAO (2004). Global Forest Resources Assessment Updates 2005-Terms and Definitions.

Husch, B., Beers, T. W., \& Kershaw, J. A. (2003). Forest Mensuration. Hoboken, NJ: Wiley \& Sons.

Kasischke, E. S., \& Christensen, N. L. J. (1990). Connecting Forest Ecosystem and Microwave Backscatter Models. International Journal of Remote Sensing, 11, 1277-1298. https://doi.org/10.1080/01431169008955093

Kinyanjui, J. M., Karachi, M., \& Ondimu, K. N. (2014). Estimating Forest Volume and Yield in the Western Blocks of the Mau Forest Complex, Kenya. Journal of Environment, Natural Resources Management and Society, 1, 59-69.

Lu, D. (2006). The Potential and Challenge of Remote Sensing-Based Biomass Estimation. International Journal of Remote Sensing, 27, 1297-1328. https://doi.org/10.1080/01431160500486732

Lu, D., Batistella, M., \& Moran, E. (2005). Satellite Estimation of Aboveground Biomass and Impacts of Forest Stand Structure. Photogrammetric Engineering \& Remote Sensing, 71, 967-974. https://doi.org/10.14358/PERS.71.8.967

Patenaude, G., Milne, R., \& Dawson, T. P. (2005). Synthesis of Remote Sensing Approaches for Forest Carbon Estimation: Reporting to the Kyoto Protocol. Environ- 
mental Science \& Policy, 8, 161-178. https://doi.org/10.1016/j.envsci.2004.12.010

Rosillo-Calle, F., De Groot, P., Hemstock, S., \& Woods, J. (2006) Biomass Assessment Handbook-Bioenergy for a Sustainable Development. Biomass Assessment Handbook, London: Earthscan.

Shimada, M., Isoguchi, O., Tadono, T., \& Isono, K. (2009). PALSAR Radiometric and Geometric Calibration. IEEE Transactions on Geoscience and Remote Sensing, 47, 3915-3932. https://doi.org/10.1109/TGRS.2009.2023909

Sombroek, W. C., Braun, H. M. H., \& van der Pouw, B. J. A. (1982). Explanatory Soil Map and Agro-Climatic Zone Map of Kenya (56 p). Report E1, Nairobi: National Agricultural Laboratories, Soil Survey Unit.

Stein, A. E., van der Meer, F. D. E., \& Gorte, B. G. H. E. (1999). Spatial Statistics for Remote Sensing (p. 300). Dordrecht: Kluwer Academic.

Steininger, M. K. (2000). Satellite Estimation of Tropical Secondary Forest Above-Ground Biomass: Data from Brazil and Bolivia. International Journal of Remote Sensing, 21, 1139-1157. https://doi.org/10.1080/014311600210119

Tansey, K., Gregoire, J. M., Stroppiana, D., Sousa, A., Silva, J., Pereira, J. M. C., Boschetti, L., Maggi, M., Brivio, P. A., Fraser, R., Flasse, S., Ershov, D., Binaghi, E., Graetz, D., \& Peduzzi, P. (2004). Vegetation Burning in the Year 2000: Global Burned Area Estimates from Spot Vegetation Data. Journal of Geophysical Research, 109, D14S03. https://doi.org/10.1029/2003JD003598

Zheng, D., Rademacher, J., Chen, J., Crow, T., Bresee, M., Le Moine, J., \& Ryu, S.-R. (2004). Estimating Aboveground Biomass Using Landsat 7 ETM+ Data across a Managed Landscape in Northern Wisconsin, USA. Remote Sensing of Environment, 93, 402-411. https://doi.org/10.1016/j.rse.2004.08.008

\section{Submit or recommend next manuscript to SCIRP and we will provide best} service for you:

Accepting pre-submission inquiries through Email, Facebook, LinkedIn, Twitter, etc. A wide selection of journals (inclusive of 9 subjects, more than 200 journals)

Providing 24-hour high-quality service

User-friendly online submission system

Fair and swift peer-review system

Efficient typesetting and proofreading procedure

Display of the result of downloads and visits, as well as the number of cited articles

Maximum dissemination of your research work

Submit your manuscript at: http://papersubmission.scirp.org/

Or contact ojf@scirp.org 